\title{
Application of Metal Injection Molding to W-Ni-Fe Heavy Alloy
}

\author{
Young Do Kim, Sung-Soo Ryu and In-Hyung Moon \\ Department of Materials Engineering, CPRC, Hanyang University, Seoul 133-791, Korea
}

Received May 10, 1999

\begin{abstract}
SYNOPSIS
A study was carried out to investigate the possibility whether MIM process could be applied to the compacting process of $\mathrm{W}-\mathrm{Ni}-\mathrm{Fe}$ heavy alloy in order to obtain an intricate shape. The multi binder system of $45 \mathrm{PW}+30 \mathrm{PE}+15 \mathrm{BW}+10 \mathrm{SA}$ was used for injection molding and compacts from the powder-binder mixture of metal powder fraction of 60 vol.\% were studied for debinding and sintering behaviors. In debinding process, heating rate in temperature range from $120^{\circ} \mathrm{C}$ to $290^{\circ} \mathrm{C}$ had an important effect on the weight loss of the binder. The binder could be fully removed by three stage debinding treatment. The microstructure of the sintered specimen was dependent on the sintering atmosphere. The $\mathrm{W}-4.9 \mathrm{wt} . \% \mathrm{Ni}-2.1 \mathrm{wt}$. $\% \mathrm{Fe}$ alloy of full sintered density was obtained by sintering at $1470^{\circ} \mathrm{C}$ for $1 \mathrm{~h}$ in a wet hydrogen atmosphere and there was no difference in microstructure compared to that of $\mathrm{W}$ heavy alloy by die compaction.
\end{abstract}

KEY WORDS

Metal injection molding, W heavy alloy, liquid phase sintering, wet hydrogen

\section{Introduction}

Tungsten heavy alloys are two-phase composites characterized by their high densities and microstructures consisting of $\mathrm{W}$ grains embedded in an alloy matrix. In general, tungsten heavy alloys have been used as kinetic energy penetrator, armor, shaped charge liners, and inertial counterweight balances due to the their unique combination of high hardness, high strength, high ductility and high density ${ }^{1,2)}$. Most of these applications require final configuration of complex shape. Thus, the final fabrication involves a great deal of machining of the expensive materials.

Metal injection molding (MIM) is an unique powder processing technique suitable for net shape manufacturing of complex shaped parts from metal, ceramics and composite $^{3-5)}$. The application of MIM to the W heavy alloys may provide an economic advantage in the mass production of complex shapes ${ }^{6}$.

In the present study, therefore, the possibility whether MIM process could be applied to the compacting process of W-Ni-Fe heavy alloy was investigated in order to obtain an intricate part without the machining process.

\section{Experimental procedure}

\subsection{Materials}

Fig. 1 and Table 1 shows that SEM morphologies and characteristics of elemental powders used in this study, respectively. W-Ni-Fe powders with composition of W$4.9 \mathrm{Ni}-2.1 \mathrm{Fe}$ (in wt.\%) were mixed in a Turbula mixer for 4 h. The binder used for the preparation of MIM feedstock was a multi-component binder system with a composition of 45 wt.\% paraffin wax (PW)-15wt.\% bees wax (BW)$30 \mathrm{wt} . \%$ polyethylene (PE)-10wt.\% stearic acid (SA). This was based on the result of previous study ${ }^{7)}$. Table 2 shows composition and characteristics of binder system used in this study.

\subsection{Mixing \& molding}

For MIM, SA was first mixed with the mixed powder for $1 \mathrm{~h}$ in a Turbula mixer. Then, the powder was mixed with the binder in a single cam mixer. The powder-binder mixture was injection molded with molding pressure of 40 $\mathrm{MPa}$ at the cylinder temperature of $125^{\circ} \mathrm{C}$ and mold temperature of $75^{\circ} \mathrm{C}$. The green density was determined by volume and weight measurement. The feedstock used in the present experiment was formulated at a solid loading of 60 vol.\%

\subsection{Debinding}

The binder of the green part was removed by the melt wicking in $0.05 \mu \mathrm{m}$-alumina powders and the thermal decomposition. Debinding process was determined on the 
basis of previous study ${ }^{7}$ and thermogravimetric analysis (TGA). Such a process had three steps of holding temperatures at $120^{\circ} \mathrm{C}, 290^{\circ} \mathrm{C}$ and $480^{\circ} \mathrm{C}$. The debinding was carried out in nitrogen up to $480^{\circ} \mathrm{C}$ and in hydrogen above $480^{\circ} \mathrm{C}$. The holding temperature step at $600^{\circ} \mathrm{C}$ was introduced as a presintering stage to provide a strength for the sample handling.
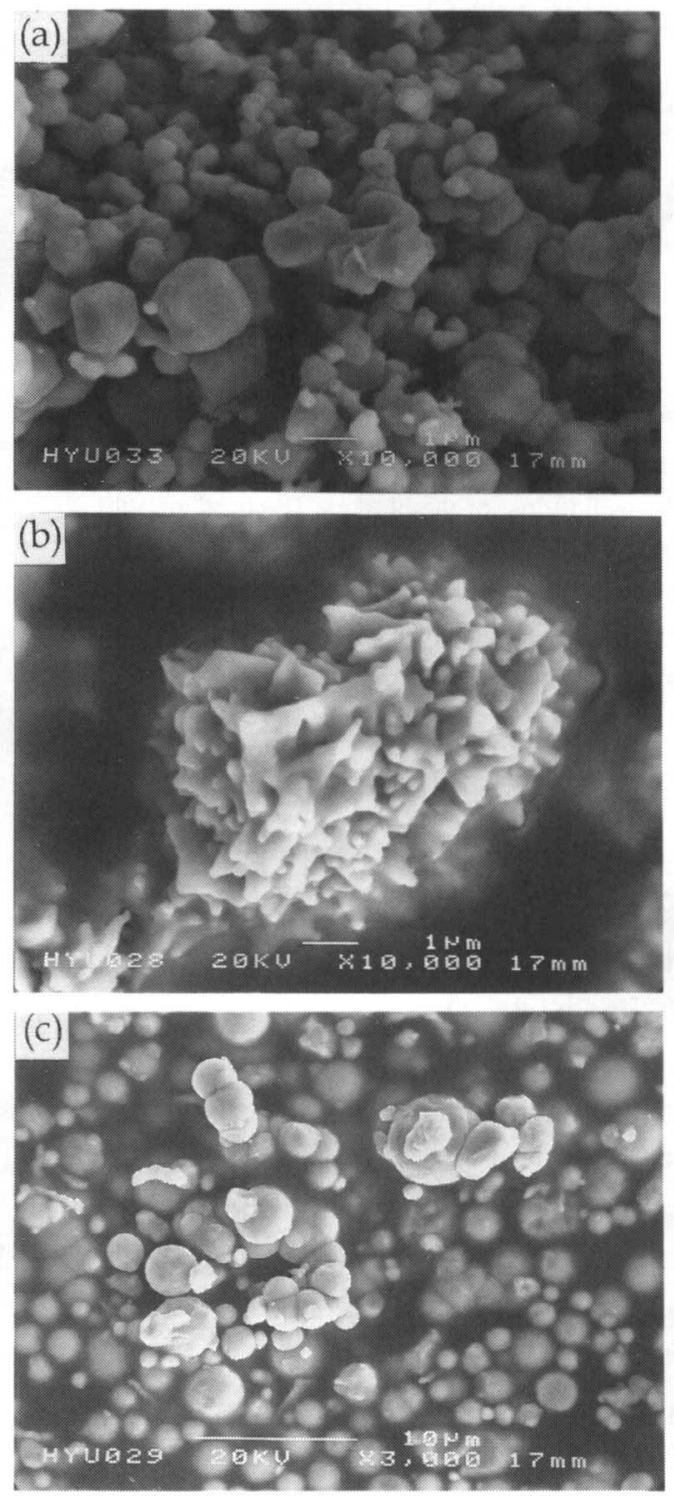

Fig.1 SEM morphologies of elemental (a) W, (b) Ni and (c) Fe powders.

Table 1 Characteristics of elemental powders used in this study.

\begin{tabular}{cccc}
\hline & $\mathrm{W}$ & $\mathrm{Ni}$ & $\mathrm{Fe}$ \\
\hline Shape & polygonal & spiky & spherical \\
Size $(\mu \mathrm{m})$ & 1.77 & 4.0 & 1.95 \\
Purity $(\%)$ & 99.9 & 99.9 & 99.7 \\
Density $\left(\mathrm{g} / \mathrm{cm}^{3}\right)$ & 19.3 & 8.91 & 7.87 \\
\hline
\end{tabular}

The amounts of the removed binder were analyzed by the measurement of the weight loss of green part after the debinding process. Debound parts were also checked for any defects generated during the debinding.

\subsection{Sintering}

The debound part was held at $800^{\circ} \mathrm{C}$ for $1.5 \mathrm{~h}$ for oxide reduction and sintered at $1460^{\circ} \mathrm{C}, 1470^{\circ} \mathrm{C}$, and $1480^{\circ} \mathrm{C}$ for $1 \mathrm{~h}$. The heating rate to the sintering temperature was $10^{\circ} \mathrm{C} /$ min and the cooling rate was $2^{\circ} \mathrm{C} / \mathrm{min}$ to $1300^{\circ} \mathrm{C}$. The sintering cycle of W heavy alloy is shown in Fig.2.

The sintered density was measured using the densimeter by Archimedes' principle. The microstructure of the sintered part was observed by the optical microscope and scanning electron microscope (SEM).

\section{Results and discussion}

\subsection{Debinding behavior}

Fig. 3 shows TGA analysis of green part for MIM W4.9Ni-2.IFe. From the results of TGA analysis and the previous study ${ }^{8)}$, the debinding process for the binder

Table 2 Composition and characteristics of the binder component.

\begin{tabular}{cccc}
\hline \hline & $\begin{array}{c}\text { Melting point } \\
\left({ }^{\circ} \mathrm{C}\right)\end{array}$ & $\begin{array}{c}\text { Density } \\
\left(\mathrm{g} / \mathrm{cm}^{3}\right)\end{array}$ & $\begin{array}{c}\text { Composition } \\
(\mathrm{wt} \%)\end{array}$ \\
\hline $\begin{array}{c}\text { Paraffin wax } \\
(\mathrm{PW})\end{array}$ & 68.3 & 0.9 & 45 \\
$\begin{array}{c}\text { Bees Wax } \\
(\mathrm{BW})\end{array}$ & 69.4 & 0.95 & 15 \\
$\begin{array}{c}\text { Polyethylene } \\
(\mathrm{PE})\end{array}$ & 114.6 & 0.93 & 30 \\
$\begin{array}{c}\text { Stearic Acid } \\
(\mathrm{SA})\end{array}$ & 77.3 & 0.85 & 10 \\
\hline
\end{tabular}

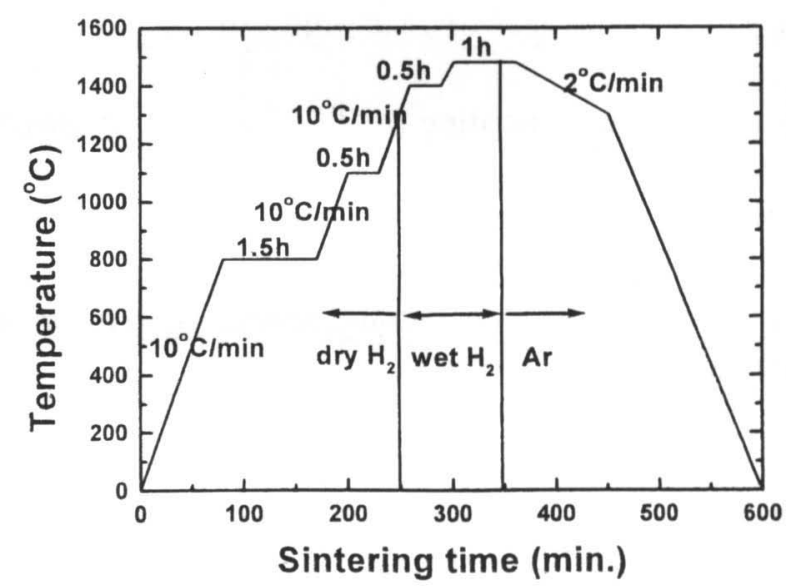

Fig.2 The sintering cycle of W-4.9Ni-2.1Fe heavy alloy used in this study. 
removal consisted of three-stage of temperature ranges from $0^{\circ} \mathrm{C}$ to $120^{\circ} \mathrm{C}, 120^{\circ} \mathrm{C}$ to $290^{\circ} \mathrm{C}$, and $290^{\circ} \mathrm{C}$ to $480^{\circ} \mathrm{C}$. By examining parameters of debinding process such as the heating rate and holding time, it was found that heating rate in temperature range from $120^{\circ} \mathrm{C}$ to $290^{\circ} \mathrm{C}$, in which most of waxes were evaporated, had an important effect on the weight loss of binder as well as the crack generation. Table 3 shows the weight loss and shape stability after debinding at various heating rates in temperature range from $120^{\circ} \mathrm{C}$ to $290^{\circ} \mathrm{C}$. As shown in this Table, the binder was removed completely after debinding process at slow heating rate of $0.5^{\circ} \mathrm{C} / \mathrm{min}$. Debinding process used in this experiment is represented in Fig.4.

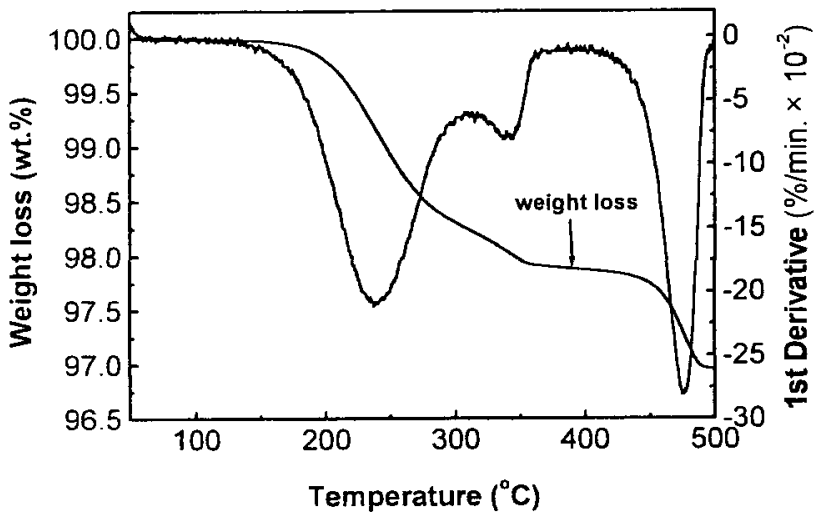

Fig.3 TGA analysis of $\mathrm{W}-4.9 \mathrm{Ni}-2.1 \mathrm{Fe}$ green part.

Table 3 The weight loss and shape stability of green parts with various debinding processes.

\begin{tabular}{lcc}
\hline \multicolumn{1}{c}{ Debinding process } & $\begin{array}{c}\text { Weight } \\
\text { loss }(\%)\end{array}$ & $\begin{array}{c}\text { Shape } \\
\text { stabilazation }\end{array}$ \\
\hline $120^{\circ} \mathrm{C}-290^{\circ} \mathrm{C}, 0.5^{\circ} \mathrm{C} / \mathrm{min}$ & 100.08 & $\mathrm{O}$ \\
$120^{\circ} \mathrm{C}-290^{\circ} \mathrm{C}, 1^{\circ} \mathrm{C} / \mathrm{min}$ & 98.29 & $\mathrm{O}$ \\
$120^{\circ} \mathrm{C}-290^{\circ} \mathrm{C}, 2^{\circ} \mathrm{C} / \mathrm{min}$ & 97.21 & $\mathrm{O}$ \\
\hline \hline
\end{tabular}

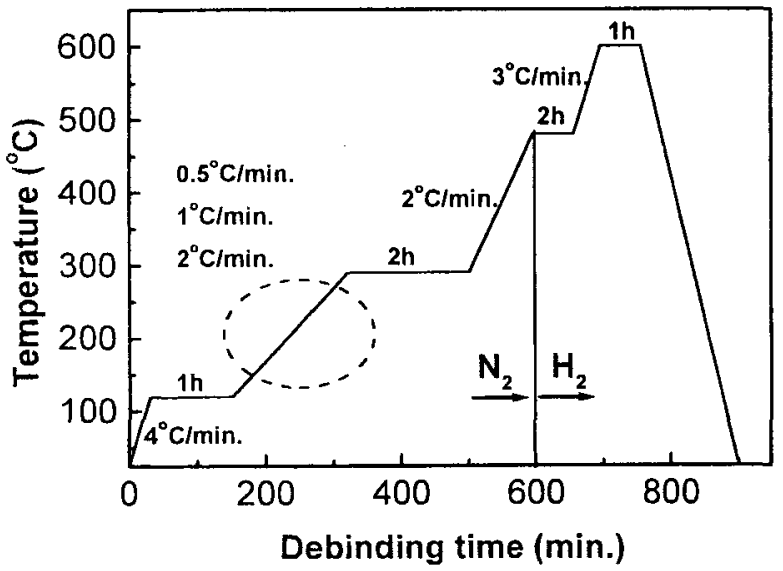

Fig.4 The debinding cycle used in this study.
Fig.5 shows the Fourier transform infrared spectroscopy (FT-IR) analysis curve for the MIM W-4.9Ni-2.l Fe specimen. The characteristic peak for organic substance as marked with asterisk in Fig.5(b), which was introduced by the binder, was not detected in the FT-IR curve for the debound part. This means that all of the binders were

(a)

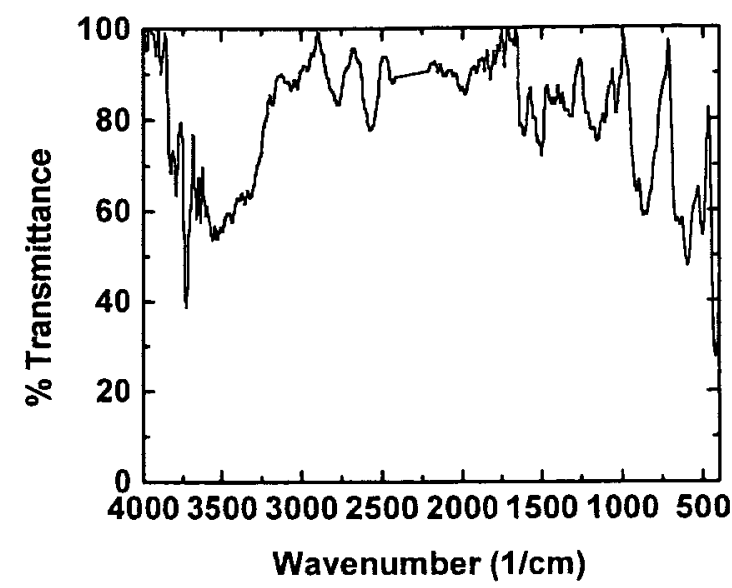

(b)

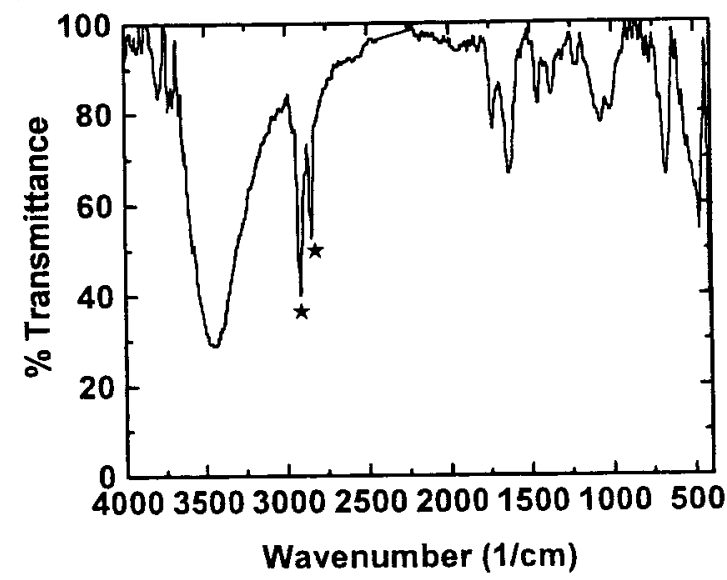

(c)

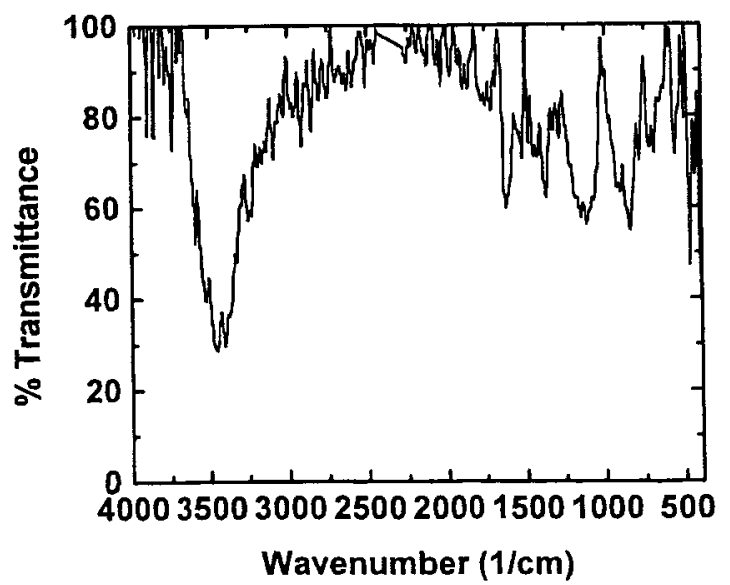

Fig.5 Result of FT-IR analysis for (a) powder, (b) green part and (c) brown part 
removed in brown part after the debinding process. The complete removal of the binder during debinding was also confirmed by carbon analysis as shown in Table 4 .

Table 4 The carbon content of the brown and sintered parts.

wt. \%)

Debinding process Brown part Sintered part

\begin{tabular}{lll}
\hline $120^{\circ} \mathrm{C} \sim 290^{\circ} \mathrm{C}, 0.5^{\circ} \mathrm{C} / \mathrm{min}$ & 0.0734 & 0.0025 \\
$120^{\circ} \mathrm{C}-290^{\circ} \mathrm{C}, 1^{\circ} \mathrm{C} / \mathrm{min}$ & 0.1168 & 0.0052 \\
$120^{\circ} \mathrm{C} \sim 290^{\circ} \mathrm{C}, 2^{\circ} \mathrm{C} / \mathrm{min}$ & 0.3556 & 0.0069 \\
\hline
\end{tabular}

(a)

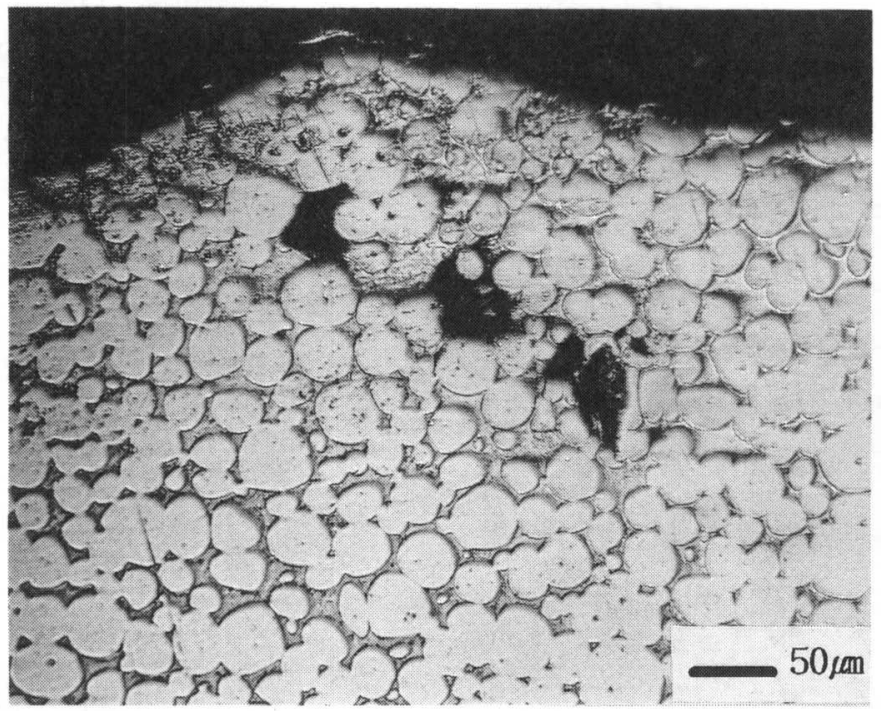

(b)

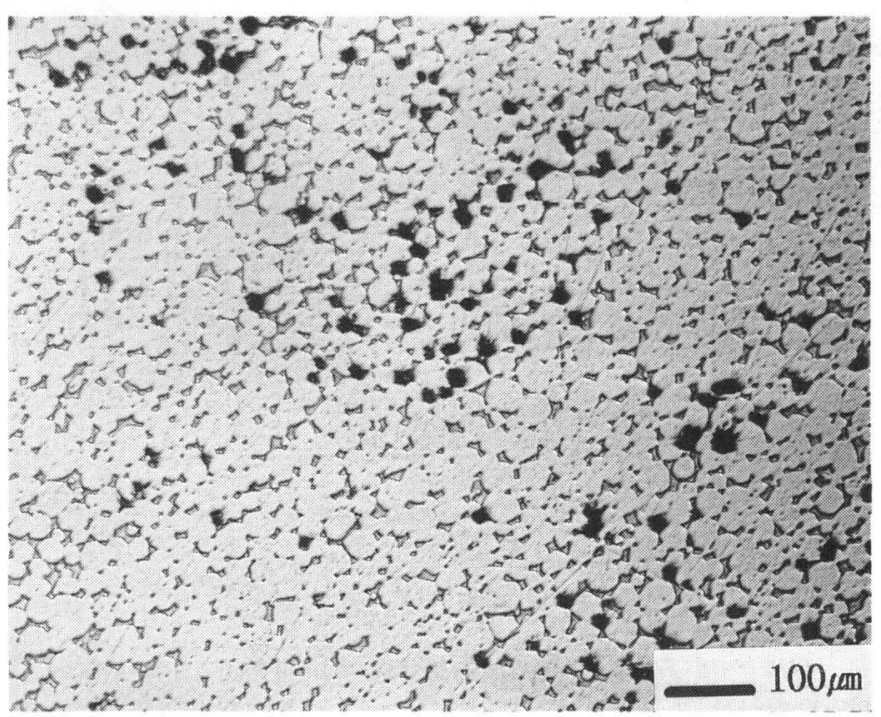

Fig.6 Optical micrographs of MIM W-4.9Ni-2.1Fe heavy alloy sintered at $1480^{\circ} \mathrm{C}$ for $1 \mathrm{~h}$ in dry hydrogen atmosphere showing (a) pore formation and (b) blister formation.

\subsection{Sintering behavior}

Fig.6 shows the microstructures of MIM W-4.9Ni-2.IFe heavy alloy sintered at $1470^{\circ} \mathrm{C}$ for $1 \mathrm{~h}$ in a dry hydrogen (dew point $-60^{\circ} \mathrm{C}$ ). As shown in this figure, the defects such as pore and blister were observed even though the sintered density was over $99 \%$ of theoretical one. It seemed to be responsible for the sintering atmosphere. Bose et $a l .{ }^{9)}$ reported that dry hydrogen often causes swelling during liquid phase sintering due to water trapping. This swelling becomes more severe with higher liquid contents or longer sintering times. It was suggested that swelling could be minimized using a wet hydrogen (dew point $20^{\circ} \mathrm{C}$ ) in the sintering process. Thus, in order to avoid defects during sintering, sintering atmosphere changed to wet hydrogen from dry hydrogen at $1250^{\circ} \mathrm{C}$ and then was held in wet

(a)

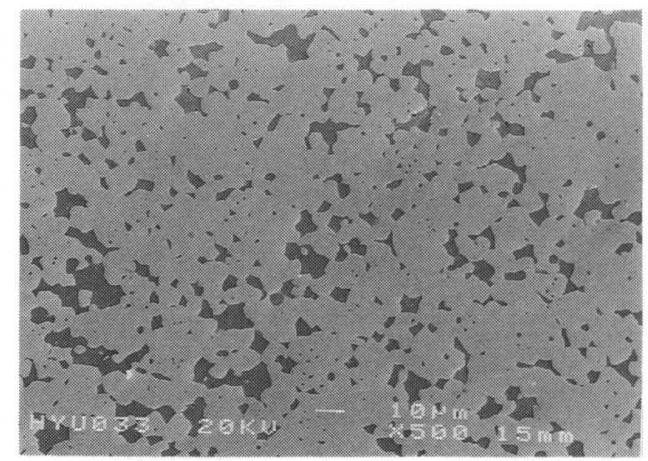

(b)

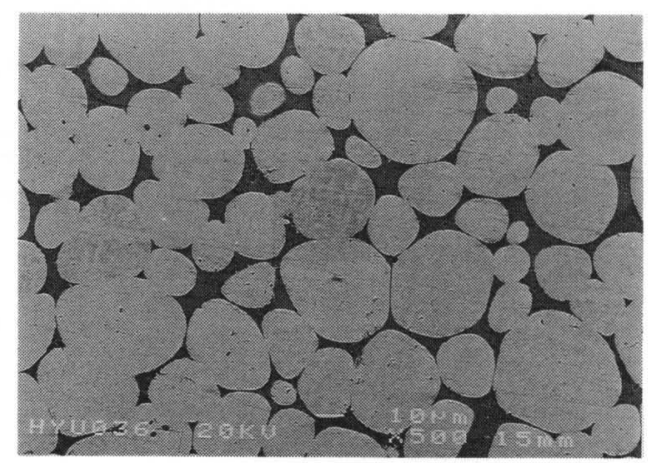

(c)

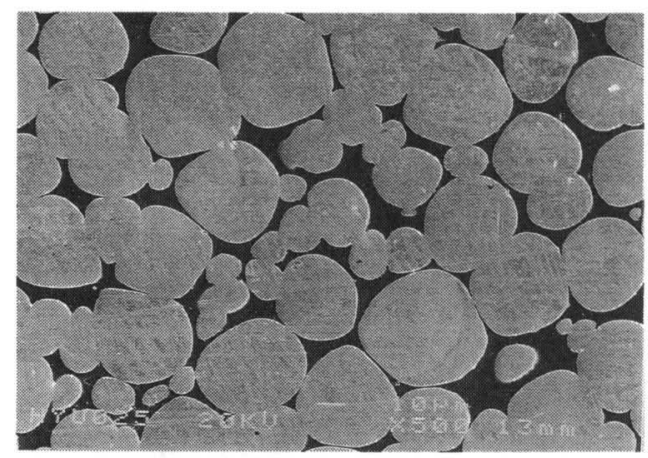

Fig.7 SEM morphologies of MIM W-4.9Ni-2.1 Fe heavy alloy sintered at (a) $1460^{\circ} \mathrm{C}$, (b) $1470^{\circ} \mathrm{C}$ and (c) $1480^{\circ} \mathrm{C}$ for $1 \mathrm{~h}$ in wet hydrogen atmosphere. 
hydrogen atmosphere up to sintering temperature.

Fig. 7 shows the microstructures of MIM W-4.9Wi-2.IFe heavy alloy sintered at $1460^{\circ} \mathrm{C}, 1470^{\circ} \mathrm{C}$ and $1480^{\circ} \mathrm{C}$ for $1 \mathrm{~h}$ in wet hydrogen atmosphere, respectively. After liquid phase sintering using wet hydrogen, nearly full density was obtained irrespective of sintering temperature and as shown in Fig.8, no blister was formed. There was no difference in microstructure compared to that of $\mathrm{W}$ heavy alloy made of die compaction.

\subsection{Microhardness of the sintered part}

Fig.8 shows microhardness change with the sintering temperature for MIM W-4.9Ni-2.1Fe specimens sintered for $1 \mathrm{~h}$ in wet hydrogen atmosphere. As shown in this figure, microhardness value decreased with increasing the sintering temperature due to the $\mathrm{W}$ grain growth. The microhardness of the top region of the sintered specimen was higher than that of the bottom region.

In W heavy alloy, there was the gravitational effect during liquid phase sintering due to the high density of $\mathrm{W}^{\mathrm{i})}$, so that the solid content increased from the top to the bottom of the sintered specimen. Accordingly, higher microhardness value in the bottom region was attributed to the gravitational effect during liquid phase sintering.

\section{Conclusion}

This research has revealed that the MIM method could possibly be applied for the fabricating process of the $\mathrm{W}$ heavy alloy with the complex shape, showing moderate molding and debinding as well as sintering characteristics.

The W-4.9wt.\%Ni-2.1wt.\%Fe heavy alloy was suitably injection molded into a complex shaped part by adopting the multi binder system of $45 \mathrm{PW}+30 \mathrm{PE}+15 \mathrm{BW}+10 \mathrm{SA}$, and the binder could be fully removed by three stage debinding treatment. The full sintered density was obtained by sintering at $1470^{\circ} \mathrm{C}$ for $1 \mathrm{~h}$ in a wet hydrogen atmosphere and there was no difference in microstructure compared to that of $\mathrm{W}$ heavy alloy by die compaction.

\section{Acknowledgement}

This work was supported by Korea Research Foundation Grant.

\section{References}

1) B.Nathan: "Many Options for Sintered Tungsten Alloys", Metal Powder Report, (1985)271-276.

2) K.J.A.Brookes: "Heavy Alloys or Advanced PM

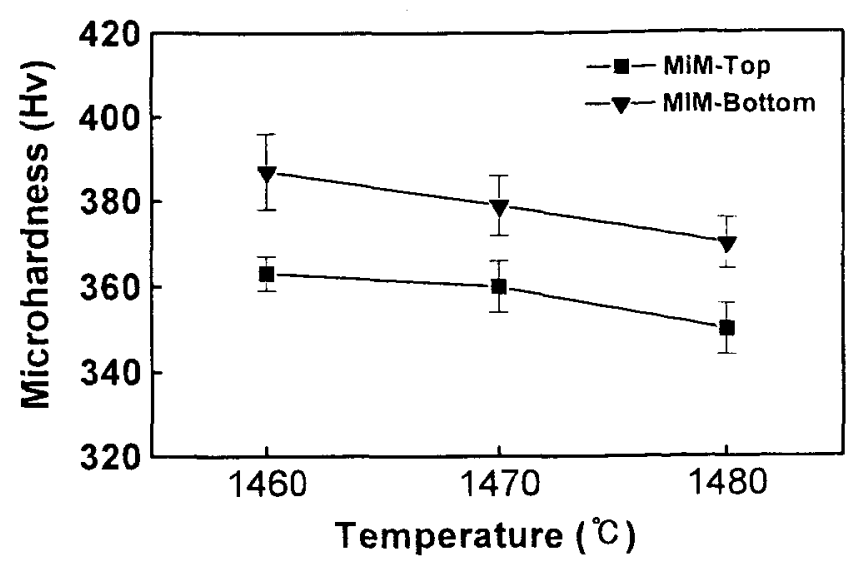

Fig.8 Microhardness values in MIM W-4.9Ni-2.IFe parts sintered for $1 \mathrm{~h}$ using wet hydrogen.

Activities", Metal Powder Report, (1984)296-298.

3) B.Haworth and P.J.James: "Injection Moulding of Powders", Metal Powder Report, 41(1986)146-149.

4) L.F.Pease: "A Perspective on the Markets and Technology for Injection Molded Metal Powder and Ceramics", Int, J. Powder Metall., 22(1986)177-184.

5) R.M.German: 'Powder Injection Molding', MPIF, Princeton, NJ, (1990).

6) A.Bose, H.Zhang, P.Kemp and R.M.German: "Injection Molding of Molybdenum Treated Tungsten Heavy Alloy", Advances in Powder Metallurgy Proc., MPIF, Princeton, NJ, (1990)401-413.

7) S.C.Yoo, B.S.Kwon, K.M.Lee, J.Choi, S.H.Ahn and I.H.Moon: "Metal Injection Molding of Sieve Size NiMo Steel Powders", Powder Injection Molding Symposium, MPIF, Princeton, NJ, (1992)229-37.

8) I.H.Moon, S.H.Kim, and J.C.Kim: "The Particle Size Effect of Cu-Powder on the Sintering of W-Cu MIM Parts", Advances in Powder Metallurgy \& Particulate Materials-1996, ed. by T.M.Cadle and K.S. Narasimhanr., MPIF, Princeton, NJ, (1996), Part 19, 147-156.

9) A.Bose, B.H.Rabin. S.Farooq and R.M.German: "Hydrogen Atmosphere and Residual Oxygen Interactions during Liquid Phase Sintering of Heavy Alloy", Horizons in Powder Metallurgy, Part II, ed. by W.A.Kaysser and W.J.Huppmann, Verlag Schmid, Freiburg, Germany, (1986)1123-1126.

10)A.Upadhaya and R.M.German: "A Mathematical Model for Gravity-Induced Distortion during Liquid-Phase Sintering", Metall. Mater. Trans A, 26A(1995)653-659. 